\title{
OCCURRENCE OF ARSENIC, LEAD, THALLIUM AND BERYLLIUM IN GROUNDWATER
}

\author{
${ }^{1}$ Abdul A.J. Mohamed, ${ }^{1}$ Ibrahim Abdul Rahman, ${ }^{2}$ Sadri A. Said and ${ }^{1}$ Lee H. Lim \\ ${ }^{1}$ Faculty of Science (FOS), Universiti Brunei Darussalam Jalan Tungku, Brunei Darussalam, BE1410, Brunei \\ ${ }^{2}$ School of Pharmacy, College of Pharmacy and Nursing, University of Nizwa, Birkat Al Mouz, \\ PB 33, PO 616, Nizwa, Sultanate of Oman
}

Received 2014-01-28; Received 2014-03-24 Accepted 2014-04-11

\begin{abstract}
The occurrence of carcinogenic and heavy metals in groundwater sources in Urban-west region of Zanzibar Island is an issue that is not very well known. This could be also coupled with the absence of drinking water treatment plants. This study for the first time reports on the occurrence and the levels of three carcinogenic metals-Arsenic ( $\mathrm{As})$, Beryllium $(\mathrm{Be})$ and lead $(\mathrm{Pb})$ in thirty groundwater samples collected from Zanzibar's Urban/West region. The levels of alkalinity, Magnesium $(\mathrm{Mg})$ and Thallium $(\mathrm{Tl})$ were also determined. The concentrations of $\mathrm{As}, \mathrm{Be}, \mathrm{TI}$ and $\mathrm{Pb}$ in the water samples were determined by the Inductively Coupled Plasma-Optical Emission Spectrometry (ICP-OES). Palintest photometry procedures were used to determine the levels of total alkalinity and magnesium. $\mathrm{Be}, \mathrm{As}, \mathrm{Tl}$ and $\mathrm{Pb}$ were not detected (nd) in some water samples. The ranges of concentrations of $\mathrm{Be}, \mathrm{As}$, TI and $\mathrm{Pb}$ in the samples were; nd to $6100 \mathrm{ng} \mathrm{L}^{-1}$, nd to $6600 \mathrm{ng} \mathrm{L} \mathrm{L}^{-1}$, nd to $11600 \mathrm{ng} \mathrm{L}^{-1}$ and nd to $31400 \mathrm{ng} \mathrm{L}^{-1}$ respectively. The levels of total alkalinity varied from 38 to $380\left(\mathrm{mg} \mathrm{L}^{-1}\right.$ as $\left.\mathrm{CaCO}_{3}\right)$. The proportions of water samples contaminated with $\mathrm{Be}, \mathrm{Tl}, \mathrm{As}$ and $\mathrm{Pb}$ were 43.3, 66.7, 70 and $96.7 \%$ respectively. About $23 \%$ of the water samples had $\mathrm{Pb}$ concentrations beyond WHO limits for safe drinking water, while 30 and $56.67 \%$ of the samples had $\mathrm{Be}$ and $\mathrm{Tl}$ concentrations beyond the US EPA's maximum limits. The concentration of arsenic in each water sample was within WHO limits. The occurrence and the levels of carcinogenic metals in water sources could be a potential cause of cancer cases in Zanzibar. Therefore, prompt action is required to control the levels of these hazardous metals, and other possible contaminants in Zanzibar's domestic water systems.
\end{abstract}

Keywords: Carcinogenic Metals, WHO, Alkalinity, Prompt Action

\section{INTRODUCTION}

Access to clean and safe drinking water is a vital component in our social-economic life. Clean and safe water is a key factor for preventing the spread of waterborne and sanitation related diseases, such as cholera and dysentery; however large number of Zanzibar population still lack access to clean and safe water.

Most of the developing countries lack access to safe water and adequate sanitation infrastructures, which often results in the death of about two million infants annually (UNICEF, 2005; Cosgrove and Rijsberman, 2000; Gomez and Nakat, 2002).

Because of its polarity and ability to form hydrogen bonds, water acquires unique properties. It is also capable of absorbing, dissolving, adsorbing, or suspending an array of different compounds (WHO, 2007). The most common toxic elements in drinking water are $\mathrm{As}, \mathrm{Cd}, \mathrm{Hg}$, $\mathrm{Zn}, \mathrm{Fe}, \mathrm{Cl}, \mathrm{Cr}$ and $\mathrm{Pb}$. The data and information for the water quality is vital in assessing its suitability for ce (FOS), Universiti Brunei Darussalam Jalan Tungku, Brunei Corresponding Author: Abdul A.J. Mohamed, Faculty
Darussalam, BE1410, Brunei 
drinking, industrial and irrigation purposes (Chen et al., 2002; Mondal et al., 1998). Toxic metals such as arsenic, beryllium, lead and thallium are ubiquitous in nature and could easily find their way into water sources including groundwater (Mendie, 2005). Arsenic and other harmful contaminants in drinking water are a natural calamity and a public health hazard. It exists in the natural systems due to anthropogenic as well as geological sources (Anawar et al., 2003; Ayoob and Gupta, 2006; Rafique et al., 2009; Smedley et al., 2002). The underground water of two sub districts of Tharparkar, Pakistan was found to be severely contaminated with arsenic and other detrimental contaminants (Tasneem et al., 2013).

Metals and other chemicals exist in nature and, even in the absence of anthropogenic activities; their levels might potentially affect the quality of groundwater and pose a risk to human health. A good example is the occurrence of arsenic in Bangladesh groundwater (Anawara et al., 2002). Arsenic as a chemical species disturbs the delicate balance of the ecosystem and affects the living world, which in the long run endangers the health of human beings (Benett et al., 2001). Arsenic in drinking water is carcinogenic if its concentration is above $300 \mathrm{ppb}$ (parts per billion). The latest data indicates that $80 \%$ of Bangladesh (40 million people) are at risk of arsenic poisoning-related diseases because the Bangladesh groundwater sources are contaminated with arsenic (Islam et al., 2003).

Acid rain, mine drainage agricultural run-off, industrial and domestic effluents have all contributed to the occurrence of metal loads in the groundwater aquifers. Because metals are non-degradable and thus in the environment they exist as persistent chemical species. In this respect, therefore, metals contaminations in groundwater are of special concern (Bhole and Ramteke, 2011; Chintana, 2002).

Groundwater contamination due to biological, physical and chemical contaminants has become a global problem. Contaminated groundwater is likely a key source of many health problems in Zanzibar Island. This problem has a great secio-economic impact on the domestic water consumers in the Island.

Spring and groundwater are the main sources of domestic water supply in Zanzibar Island, but currently the island is experiencing a severe water shortage. Zanzibar urban-west region is the densiestpopulated region of anzibar Island and there is a continuous increase in water consumption demand. In many parts of the island, large proportion of the population lack access to safe clean water. The water sources are threatened by contamination due to increased urbanization, poor wastewater drainage and other environmental pollution caused by the lack of proper garbage collection and waste disposal.

As there are no drinking water treatment facilities in Zanzibar, it is necessary to monitor frequently the water quality at all sources of domestic water supply to guarantee its safety to the consuming population. Recent study has shown that the levels of hexavalent chromium and copper in some groundwater sources in Zanzibar were beyond WHO recommended limit (Abdul et al., 2013). The monitoring of water quality is thus essential for averting both acute and chronic toxicities. Therefore, the present study is a contribution for the assessment of the occurrence and the levels of $\mathrm{As}, \mathrm{Be}, \mathrm{Pb}, \mathrm{Tl}$ and $\mathrm{Mg}$ in groundwater from selected domestic water sources in the Zanzibar islands. The alkalinity levels in the studied water sources was also investigated.

\section{MATERIALS AND METHODS}

\subsection{Sampling}

In December 2012, thirty water samples were collected from different areas of the Zanzibar Urban/West region and its territories. Geographic coordinates of all sampling points were recorded using the Global Positioning System (GPS). Sampling positions are shown in Fig. 1.

The sources of the collected water samples were; springs, public bore wells, private bore wells, open hand dug wells and closed hand dug wells. Samples were collected in pre-cleaned polyethylene bottles. The handling, storage and preparation of the samples were done in accordance with the standard EPA method 2007.

\subsection{Analytical procedure}

Palintest photometry procedures were used to determine the levels of the total alkalinity and magnesium, while, the Inductively Coupled PlasmaOptical Emission Spectrometry (ICP-OES) method was used to determine the concentrations of dissolved Arsenic (As), Thallium ( $\mathrm{Tl})$, lead $(\mathrm{Pb})$ and Beryllium (Be). 


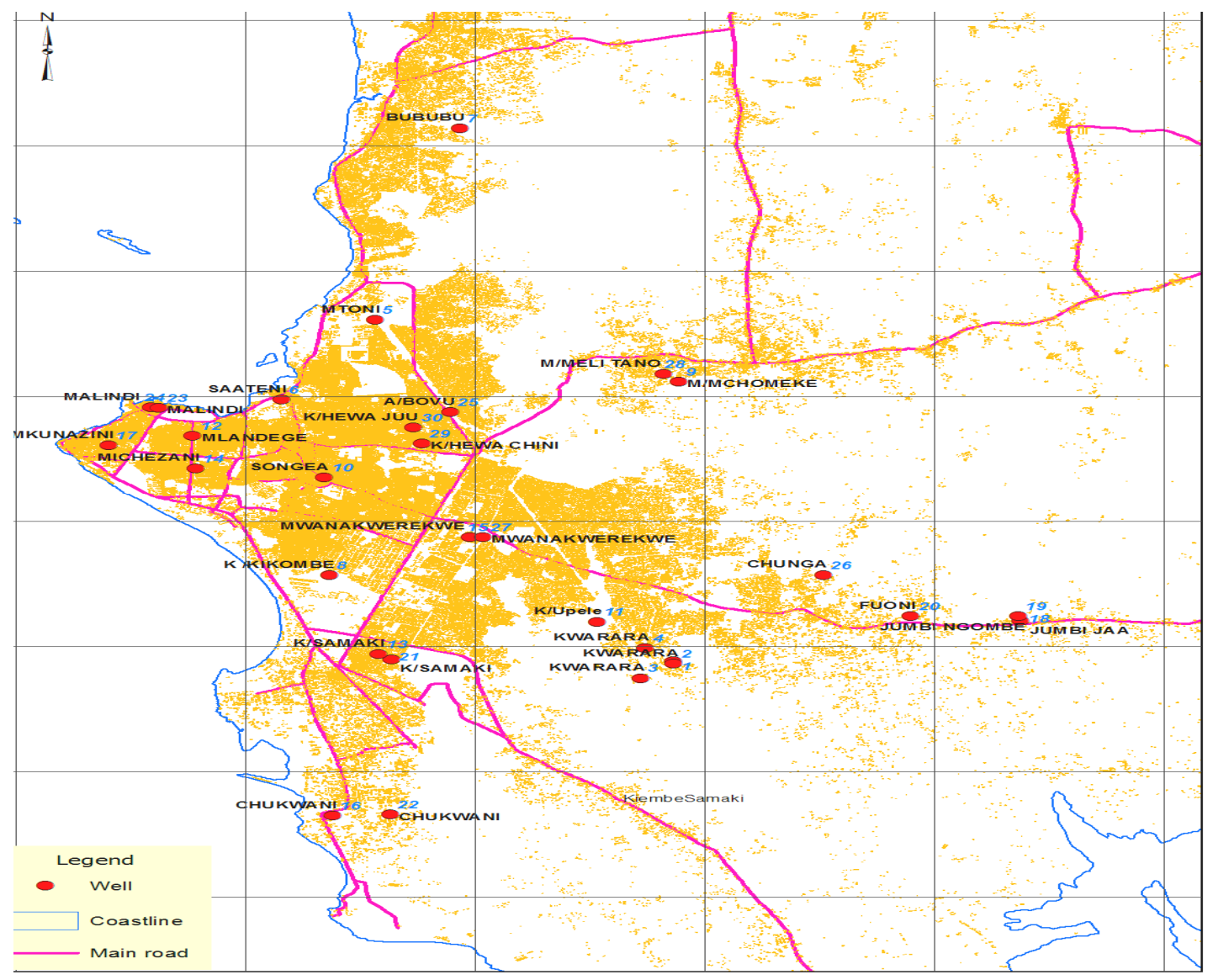

Fig. 1. Map of sampling sites in Zanzibar Urban-West Region

\section{RESULTS}

Table 1 shows the levels of alkalinity, magnesium, arsenic, lead, thallium and beryllium in the analyzed water samples. Also presented in Table 1 are the maximum permissible limits for some of the studied metals as recommended by the US EPA (2009) and WHO (2008). The levels of alkalinity ranged from 38 to $380 \mathrm{mg} \mathrm{L}^{-1}$ as $\mathrm{CaCO}_{3}$, highest-level was measured at site 23 (Malindi). The alkalinity levels measured at sites 1-4 (Kwarara sampling points) were relatively lower as compared to other areas (Table 1). Therefore, water sources in Kwarara areas might have higher degree of corrosivity. Indeed, these sites have been documented for low alkalinity levels (Abdul et al., 2014). Concentrations of Magnesium (Mg) varied from 1.0 to $34 \mathrm{mg} \mathrm{L}^{-1}$. The concentrations of Arsenic
(As) varied from non-detectable (nd) to $6600 \mathrm{ng} \mathrm{L}^{-1}$, Jumbi ngombe had the highest arsenic level. Beryllium (Be) levels ranged from nd to $6100 \mathrm{ng} \mathrm{L}^{-1}$. Indeed, traces of lead $(\mathrm{Pb})$ were present in all water samples with the exception of sampling site 12 (Mlandege). The highest concentration of lead detected was $31400 \mathrm{ng} \mathrm{L}^{-1}$ at sampling site 3 (Kwarara). Thallium (Tl) concentrations varied from nd to $11600 \mathrm{ng} \mathrm{L}^{-1}$ (Table 1 and 2), site 15 (Mwanakwerekwe) contained the highest $\mathrm{Tl}$ level. Anthropogenic environmental pollution due to activities such as improper disposal of wastes, domestic effluents and landfill leachate are the main causes of groundwater contamination in Zanzibar Island. At least one of each of the water sources (except spring water sources) have been contaminated with As, $\mathrm{Be}, \mathrm{Pb}$ and $\mathrm{Tl}$. Nevertheless, only Beryllium (Be) was not detected in spring water sources (Table 3). 
In summary, the proportions of the water samples contaminated with the four hazardous metals were 43.3, 66.7, 70 and 96.7\%, for Beryllium (Be), Thallium (Tl), Arsenic (As) and lead $(\mathrm{Pb})$ respectively (Table 1). Furthermore, $23.3 \%$ of the water samples had $\mathrm{Pb}$ concentrations above the WHO limit. While, 56.67\% and $30 \%$ are the respective proportions of the water samples with $\mathrm{Tl}$ and Be levels beyond the US EPA's maximum limits. All water samples contained arsenic within the WHO concentration limit (Fig. 2 and 3 ).

Table 1. The concentrations of trace metals and levels of alkalinity in the drinking water samples

\begin{tabular}{|c|c|c|c|c|c|c|c|}
\hline Sample & Source & $\begin{array}{l}\text { Alkalinity } \\
\text { (as } \mathrm{CaCO}_{3} \mathrm{mg} / \mathrm{L} \text { ) }\end{array}$ & $\begin{array}{l}\mathrm{Mg} \\
(\mathrm{mg} / \mathrm{L})\end{array}$ & As(ng/L) & $\mathrm{Be}(\mathrm{ng} / \mathrm{L})$ & $\mathrm{Pb}(\mathrm{ng} / \mathrm{L})$ & TI(ng/L) \\
\hline 1 & CHDW & 38 & 7.5 & 0 & 200 & 20800 & 900 \\
\hline 2 & OHDW & 42 & 7.5 & 0 & 500 & 26200 & 0 \\
\hline 3 & OHDW & 65 & 9.0 & 0 & 500 & 31400 & 0 \\
\hline 4 & OHDW & 65 & 4.0 & 0 & 400 & 9600 & 2800 \\
\hline 5 & SW & 228 & 7.0 & 2100 & 0 & 6600 & 6000 \\
\hline 6 & PBW & 240 & 2.5 & 2900 & 0 & 3400 & 4100 \\
\hline 7 & SW & 240 & 8.0 & 470 & 0 & 600 & 430 \\
\hline 8 & PBW & 255 & 6.0 & 480 & 0 & 370 & 5700 \\
\hline 9 & PBW & 183 & 2.5 & 4600 & 0 & 500 & 7100 \\
\hline 10 & CHDW & 130 & 9.0 & 3700 & 0 & 2200 & 8600 \\
\hline 11 & PBW & 205 & 5.0 & 5300 & 0 & 5700 & 9500 \\
\hline 12 & BWP & 330 & 1.0 & 3700 & 0 & 0 & 7800 \\
\hline 13 & CHDW & 200 & 6.0 & 2500 & 0 & 1100 & 7400 \\
\hline 14 & CHDW & 273 & 9.0 & 2500 & 0 & 2500 & 7500 \\
\hline 15 & BWP & 250 & 5.0 & 380 & 0 & 1000 & 11600 \\
\hline 16 & BWP & 260 & 34.0 & 3600 & 0 & 3200 & 9700 \\
\hline 17 & CHDW & 290 & 7.0 & 3900 & 0 & 1200 & 7600 \\
\hline 18 & OHDW & 330 & 7.0 & 4900 & 0 & 3200 & 8400 \\
\hline 19 & OHDW & 228 & 9.5 & 6600 & 0 & 1100 & 9600 \\
\hline 20 & CHDW & 250 & 9.0 & 4900 & 0 & 2900 & 7400 \\
\hline 21 & CHDW & 278 & 8.5 & 4600 & 0 & 900 & 9300 \\
\hline 22 & CHDW & 168 & 9.0 & 0 & 5700 & 4800 & 0 \\
\hline 23 & BWP & 380 & 16.0 & 5100 & 4900 & 12000 & 100 \\
\hline 24 & BWP & 315 & 7.5 & 3000 & 6100 & 15600 & 0 \\
\hline 25 & BWP & 273 & 9.0 & 1000 & 6000 & 15100 & 0 \\
\hline 26 & PBW & 250 & 7.5 & 900 & 5600 & 10800 & 0 \\
\hline 27 & BWP & 188 & 6.0 & 0 & 5500 & 2900 & 0 \\
\hline 28 & OHDW & 135 & 4.0 & 0 & 5500 & 4600 & 0 \\
\hline 29 & OHDW & 142 & 9.5 & 0 & 5600 & 200 & 0 \\
\hline 30 & OHDW & 273 & 7.0 & 0 & 5200 & 4400 & 0 \\
\hline \multicolumn{2}{|c|}{ WHO guidelines* } & 50 & 10000.0 & & 10000 & & \\
\hline \multicolumn{2}{|l|}{ USEPA* } & & 10000.0 & 4000 & 15000 & 2000 & \\
\hline
\end{tabular}

Table 2. Highest concentration/level of the measured water samples' parameters

\begin{tabular}{lcll}
\hline Parameters & Maximum concentration detected & Water source & Site and name \\
\hline Magnesium & 34 & BWP & $16($ Chukwani) \\
Total alkalinity & 380 & BWP & 23(Malindi) \\
Beryllium & 6100 & BWP & 24(Malindi) \\
Arsenic & 6600 & OHDW & $19($ Jumbi Ng'ombe) \\
Thallium & 11600 & BWP & $15($ Mwanakwerekwe) \\
Lead & 31400 & OHDW & 3(Kwarara) \\
\hline
\end{tabular}


Abdul A.J. Mohamed et al. / American Journal of Environmental Science 10 (2): 164-170, 2014

Table 3. Proportions (percentage occurrences) of the measured water samples' parameters

\begin{tabular}{|c|c|c|c|c|c|c|}
\hline Water source & $\begin{array}{l}\mathrm{Mg} \\
\text { occurrence } \\
(\%)\end{array}$ & $\begin{array}{l}\text { Total Alkalinity } \\
\text { occurrence } \\
(\%)\end{array}$ & $\begin{array}{l}\mathrm{Be} \\
\text { occurrence } \\
(\%)\end{array}$ & $\begin{array}{l}\text { As } \\
\text { occurrence } \\
(\%)\end{array}$ & $\begin{array}{l}\mathrm{Tl} \\
\text { occurrence } \\
(\%)\end{array}$ & $\begin{array}{l}\mathrm{Pb} \\
\text { occurence } \\
(\%)\end{array}$ \\
\hline$\overline{\text { SW }}$ & 100 & 100 & NIL & 100.0 & 100.0 & 100.0 \\
\hline PBW & 100 & 100 & 20.0 & 100.0 & 80.0 & 100.0 \\
\hline BWP & 100 & 100 & 57.1 & 85.7 & 57.1 & 85.7 \\
\hline OHDW & 100 & 100 & 66.7 & 33.3 & 44.4 & 100.0 \\
\hline CHDW & 100 & 100 & 28.6 & 71.4 & 85.7 & 100.0 \\
\hline
\end{tabular}

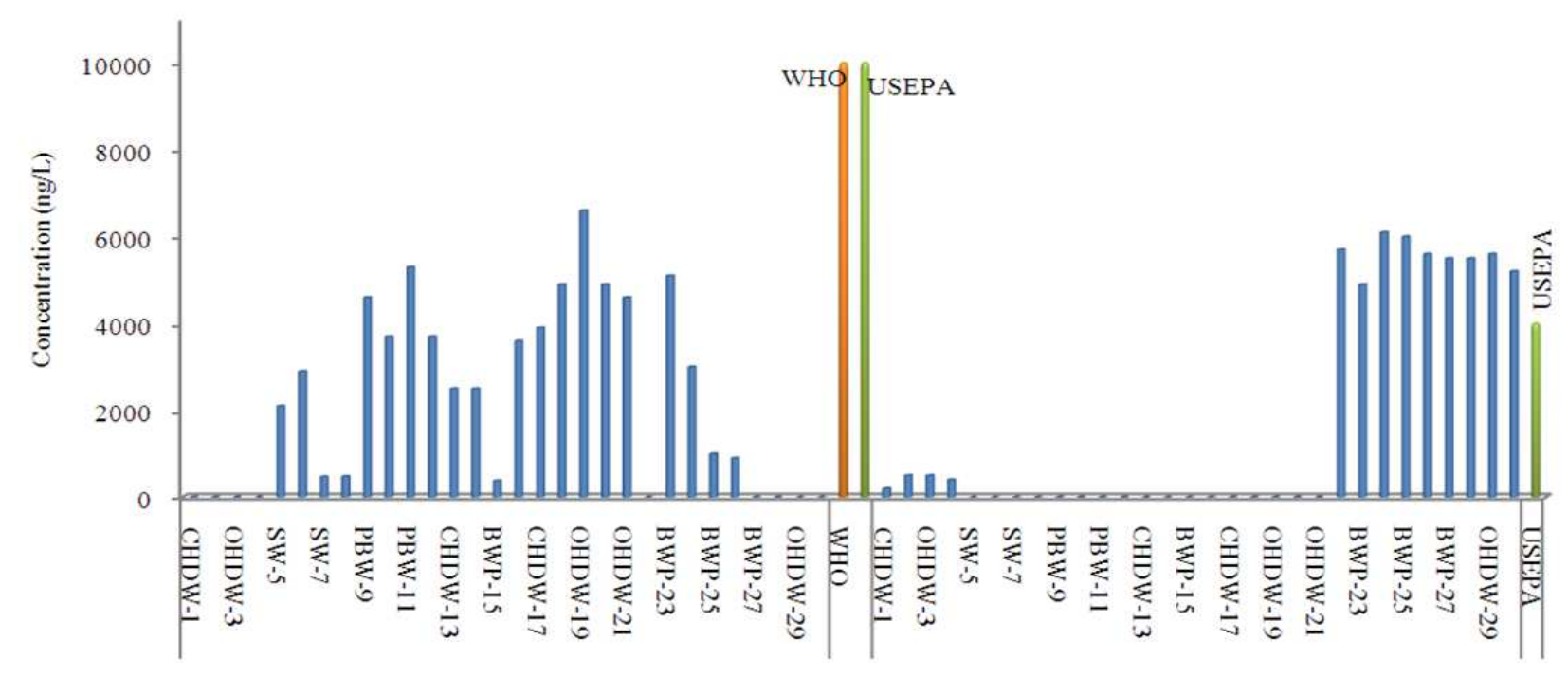

Fig. 2. Comparison of As and Be values to maximum allowed limits (USA EPA, 2009) and (WHO, 2008)

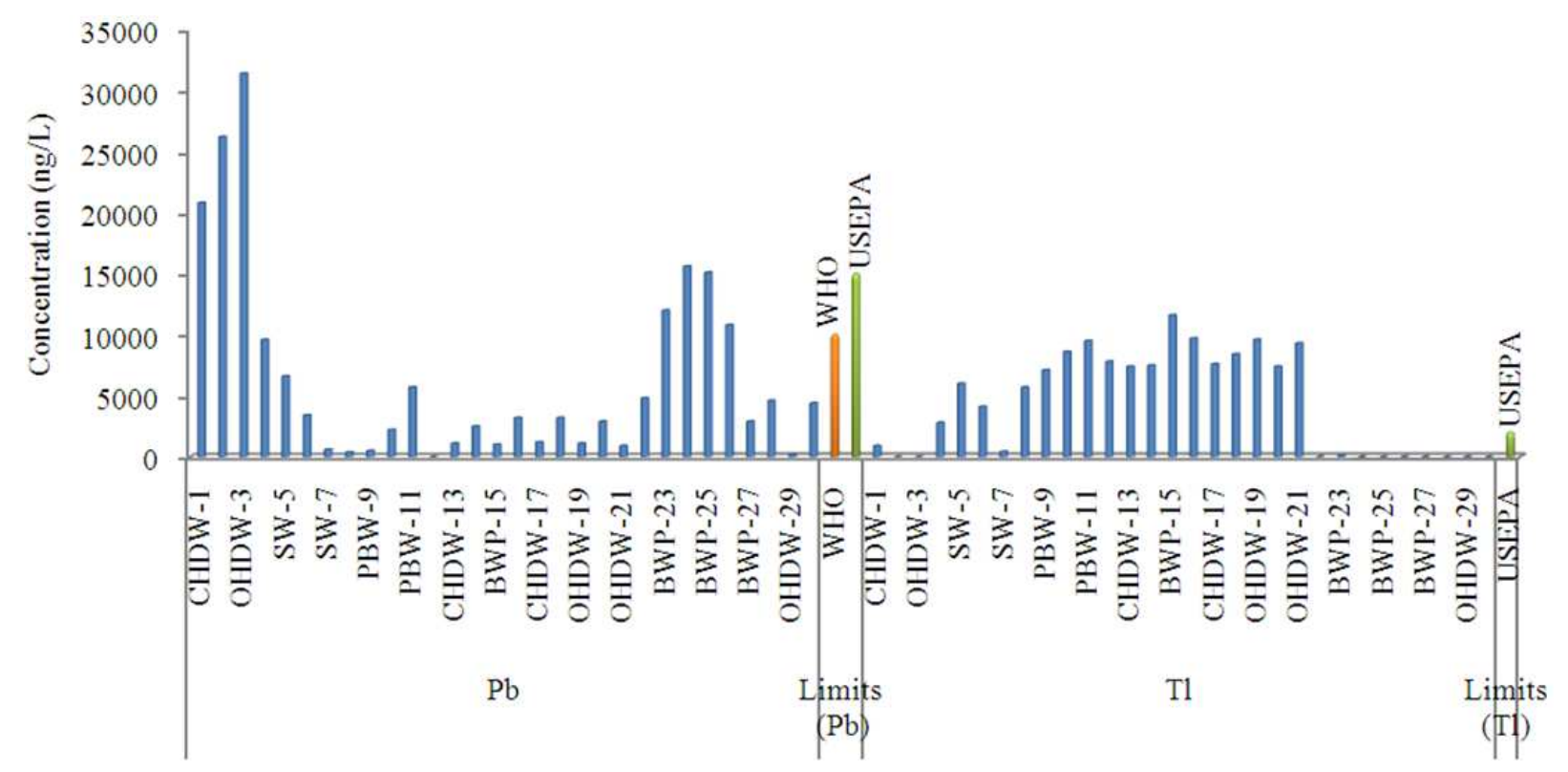

Fig. 3. Comparison of $\mathrm{Pb}$ and $\mathrm{Tl}$ values to maximum allowed limits (US EPA, 2009) and (WHO, 2008) 


\section{DISCUSSION}

The data obtained in the present study showed that, among the three analyzed carcinogenic elements, arsenic occurred at concentrations below the WHO guidelines for safe drinking water. Although arsenic might occur naturally in the environments, but its occurrence in the studied water sources is most likely of anthropogenic origin. Water site 19 (Jumbi ngombe) had the highest arsenic level, which is possibly a result of arsenic containing fertilizer used at onsite paddy farms, as well as landfill leachate. Some of the water samples had concentrations of lead, beryllium and thallium higher than those set by WHO and the US EPA. Plausible causes for lead occurrence in the majority of water samples could be from natural and anthropogenic sources. Lead is an abundant, naturally occurring metal. Wide application of lead $(\mathrm{Pb})$ in building materials, lead acid batteries, some insecticides and lead-based paints are a possible cause of the broad distribution of lead $(\mathrm{Pb})$ in the water sources and other systems. Moreover, airborne lead entering water sources via precipitation and tetraethyl lead used in gasoline is also among the key contributor of lead contaminants in groundwater aquifers.

The wide distribution of thallium in the Earth's crust is a possible reason for its occurrence in some of the water samples. Nevertheless, the uses of pharmaceutical products, insecticides and rodenticides containing thallium might be a key factor in the significant increase of thallium levels in Zanzibar's groundwater sources. Zanzibar faces growing importation of obsolete electronics, which in turns dumped improperly; therefore, this might be the possible cause for the beryllium contamination in the groundwater bodies. In addition, the poor drainage systems in Zanzibar cause contaminants to be carried by runoff from one point to another.

\section{CONCLUSION}

Some of the groundwater sources in Zanzibar Island are contaminated with trace amounts of $\mathrm{As}, \mathrm{Be}, \mathrm{Pb}$ and $\mathrm{Tl}$. The levels of $\mathrm{Be} \mathrm{Pb}$ and $\mathrm{Tl}$ exceeded the accepted international limits for safe drinking water. In this regard, prompt action is required to mitigate this apparent health risk. The present study provides a baseline data and information for current and future domestic water quality monitoring programs in Zanzibar.

Because of the time constraint, this study focused only on the selected metals at selected water-sampling points. Therefore, further studies on assessing water quality in other regions of the Island are needed because the level of contamination may vary from one area to another. The present study could not look at the epidemiological association of these metals and Zanzibar cancer patients. There is also a need to undertake epidemiological studies about the presence and the levels of carcinogenic metals from patients with cancer cases. It is also important to establish drinking water treatment plants at different locations of the Island; this can help to monitor different water parameters on daily basis.

\section{ACKNOWLEDGMENT}

We highly acknowledge to His Majesty Government of Brunei Darussalam for funding this project, Office of second vice president of Zanzibar for accepting and giving permission to undertake this study, Malcolm Anderson for useful comments on the earlier draft of this manuscript. We also thank Hjh Faridah, Azzlin, Najib and other UBD chemistry laboratory staffs for their tireless assistance.

\section{REFERENCES}

Abdul, A.J.M., A. Ibrahim and H.L. Lee, 2014. Effect of rainfall variability on ph and electrical conductivity of springs and groundwater in zanzibar urban west region. Asian J. Applied Sci., 2: 23-35.

Abdul, A.J.M., A. Ibrahim, A.S. Sadri, H.L. Lee and S. M. Islam, 2013. Levels of hexavalent chromium, copper and total hardness in springs and underground water in Zanzibar Island. Asian $\mathrm{J}$. Applied Sci., 5: 212-219.

Anawar, H.M., J. Akai, K. Komaki, H. Terao and T. Yoshioka et al., 2003. Geochemical occurrence of arsenic in groundwater of Bangladesh sources and mobilization processes. J. Geochemical Exp., 77: 109-131. DOI: 10.1016/S0375-6742(02)00273-X

Anawara, H.M., J. Akaib, K.M.G. Mostofac, S. Safiullahd and S.M. Tareqd, 2002. Arsenic poisoning in groundwater health risk and geochemical sources in Bangladesh. Environ. Int., 27: 597-604. DOI: 10.1016/S0160-4120(01)00116-7

Ayoob, S. and A.K. Gupta, 2006. Floride in drinking water a review on the status and stress effect effects. Critical Rev. Environ. Sci. Technol., 36: 433-487. DOI: $10.1080 / 10643380600678112$ 
Benett, P.M., P.D. Jepson, R.J. Law, B.R. Jonesb, T. Kuiken et al., 2001. Exposure to heavy metals and infectious disease mortality in Harbour porpoises from England and Wales. Environ. Pollut., 112: 33-40. DOI: 10.1016/S0269-7491(00)00105-6

Bhole, V. and D.S. Ramteke, 2011. Preferential adsorption of heavy metal on activated carbon. Bangladesh J. Sci. Indus. Res., 46: 211-218. DOI: 10.3329/bjsir.v46i2.2572

Chen, A.S.C., K.A. Fields, T.J. Sorg and L.L. Wang, 2002. Field evaluation of as removal by conventional plants. J. Am. Water Works Assoc., 94: 64-77.

Cosgrove, W.J. and Rijsberman, 2000. World Water Vision: Making Water Everybody's Business. 1st Edn., Earthscan, ISBN-10: 185383730X, pp: 108.

Gomez, J.D. and A.C. Nakat, 2002. Community participation in water and sanitation. Water Int., 27: 343-353. DOI: 10.1080/02508060208687014

Islam, M.J., S.M.H. Uddin, M.W. Zaman, R.I. Mahmood and M.S. Rahman, 2003. Toxicity assessment of groundwater in different aquifers of khagrachari in Bangladesh. Asian J. Plant Sci., 2:257-260. DOI: 10.3923/ajps.2003.257.260

Mendie, U., 2005. The Nature of Water. In: The Theory and Practice of Clean Wate Production for Domestic and Industrial Use, Mendie, U. (Ed) Lacto-Medals, Lagos, pp: $1-21$.

Mondal, B.K., G. Samanta, T.R. Choudhuri and R.K. Dhar, 1998. A detailed study report on 'Fakirpara' a very small arsenic affected village of west Bengal-A micro level study. Proceeding of the International Conference on Arsenic Population of Ground Water in Bangladesh, Sept. 8-12, Dhaka
Rafique, T., S. Naseem, T.H. Usmani, E. Bashir and F.A. Khan et al., 2009. Geochemical factors controlling the occurrence of high fluoride groundwater in the Niger Parker area, Sindh, Pakistan. J. Harzadous Materials, 171: 424-430.

Smedley, P.L., H.B. Nicolli, D.M.J. Macdonald, A.J. Barros and J.O. Tullio, 2002. Hydrogeochemistry of arsenic and other inorganic constituents in groundwater from La Pampa, Argentina. Applied Geochem., 17: 259-284. DOI: 10.1016/S08832927(01)00082-8

Tasneem, G., K. Kapil, D.B. Hassan and I.A.N. Shahid, 2013. Evalutation of high levels of floride, arsenic species and other physicochemical parameters in underground water of two sub districts of the Tharkapar, Pakistan: A multivariate study.

UNICEF., 2005. National Rural water supply and Sanitation investment programme. Final draft, pp: 1.

US EPA, 2009. Consumer Factsheet on: THALLIUM. US Environmental Protection Agency.

WHO, 2007. Quality Assurance of Pharmaceuticals: A Compendium of Guidelines and Related Materials. 1st Edn., World Health Organisation, Geneva, ISBN-10: 9241547081, pp: 409.

WHO, 2008. Guidelines for drinking-water quality. Recommendations. World Health Organization. 